UDK: 2-455:616.715(497.2)

doi: $10.5937 /$ gads1348043T

\title{
CEPHALOMETRIC CHARACTERISTICS OF CHILDREN AND ADOLESCENTS FROM THE EASTERN RHODOPE REGION - BULGARIA
}

\author{
Slavi Tineshev, Ivica Dimov \\ University of Plovdiv "Paisii Hilendarski", Faculty of Biology, \\ Department of " Human Anatomy and Physiology", \\ 24 Tsar Assen Str., 4000, Plovdiv, Bulgaria \\ e-mail: stineshev@abv.bg
}

\begin{abstract}
The purpose of this paper is to characterize the age dynamics and specificity of the developmental processes of head features in children and adolescents from the region of Eastern Rhodope. To achieve this goal we used transversal data collected for 1481 children and adolescents. 8 head and facial features were measured by the classical methodology of Martin-Saller (1957). Based on the directly recorded features, four indices were calculated. It is a peculiarity of the postnatal growth of all cephalometric features that growth curves are not intersected. Results show that boys have higher dimensions of the features that characterize the cranial and facial parts of the head than those of girls. The dimensions of the cranial part are ahead in its development in comparison to the dimensions of the facial part of the head, as it was observed in both sexes. In both boys and girls, the width cephalometric features complete their growth earlier than the height features.The shape of the head in the children and adolescents under observation is from the category "mesocephalic", and wider facial shapes dominate in both sexes.
\end{abstract}

Key words: cephalometric characteristics, children, mesocephalic

\section{Introduction}

The growth of head has a specificity which distinguishes it from the growth of other body parts. A child's head is different from the head of a grown-up not only in its metric characteristics, but also in the ratio between head dimensions, i.e. in their proportionality.

The growth of head dimensions is closely related to brain development. Starting from the earliest stages of embryonic development, the brain is closest to its final values in weight. The weight of a newborn's brain is $25 \%$ of the weight of an adult brain, and body weight is $5 \%$. At the age of 10 the weight of the brain is $95 \%$ that of adults, while the body mass is $50 \%$ (Tanner, 1962). In connection with this, the skull, which houses the brain, reaches its final size earlier than other parts of the skeleton. Accordingly, the head size increases intensivelly in the early stages of childhood.

The growth of head involves not only the absolute increase of its individual sizes, but also the alteration of its proportions. Assuming that an adult's head size is $100 \%$, at birth the width is $55-60 \%$, height $-40-45 \%$, and length $-30-35 \%$ of the values in an adult. This explains the different duration of growth of these features. 
The purpose of this paper is to characterize the age dynamics and specificity of these developmental processes of head features in children and adolescents from the region of Eastern Rhodope.

\section{Material and methods}

To achieve this goal we used transversal data collected for 1481 children and adolescents (699 boys and 782 girls). 8 head and facial features were measured by the classical methodology of Martin-Saller (1957): length, width, height and horizontal circumference of the head, also cheek-bone width, the width of the mandible, morphologic facial height and physiognomic height of the face. Four indices were calculated based on the directly recorded features.

The material was processed by means of the statistical package "STATISTICA 6.0", using descriptive statistics. In order to establish the statistically significant gender and intergroup differences in the values obtained, we used t-test of Student at a level of significance $\mathrm{P} \leq 0.05$.

\section{Results and discussion}

It is a peculiarity of the postnatal growth of all cephalometric features that growth curves are not intersected. Regarding head features, that fact has also been confirmed by other authors (Mladenova 2003, Nikolova2008), but when it comes to cephalic-facial features in the populations surveyed by these authors, there is an expressive intersection during the puberty period (between the age of 12-13), when boys get ahead of girls in values.

The length of head, throughout the observed age period, is higher in boys, the differences in 7-year-olds are $0.52 \mathrm{~cm}$, and in 17-year-olds $-0.77 \mathrm{~cm}$ (figure 1). In all age groups, gender differences were statistically significant $(\mathrm{p} \leq 0.05)$. At insignificant annual growth, nevertheless it emerges clearly that for boys it is highest between the ages of 10-11 $(0.29 \mathrm{~cm})$, while for girls it is between the ages of 12 and 13 and $15-16(0.27$ and $0.25 \mathrm{~cm}$ respectively).

During the growth period between 7-17 years of age, the length of the observed cephalometric feature has become greater, $1.08 \mathrm{~cm}$ in boys and $0.83 \mathrm{~cm}$ in girls. According to our data, the head length of 7 -year-old boys is $94.29 \%$ of that of 17 -year-olds, and for girls $-95.43 \%$.

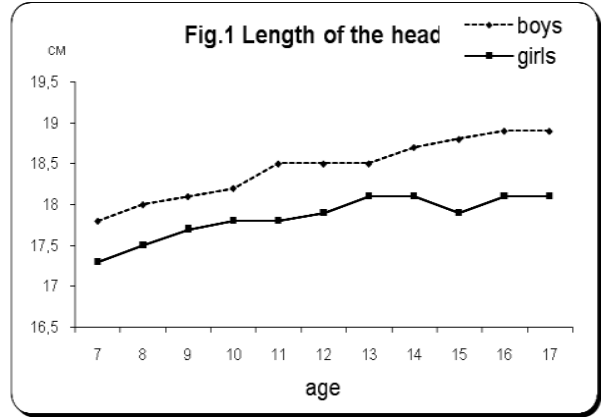

Figure 1. Lenght of the head

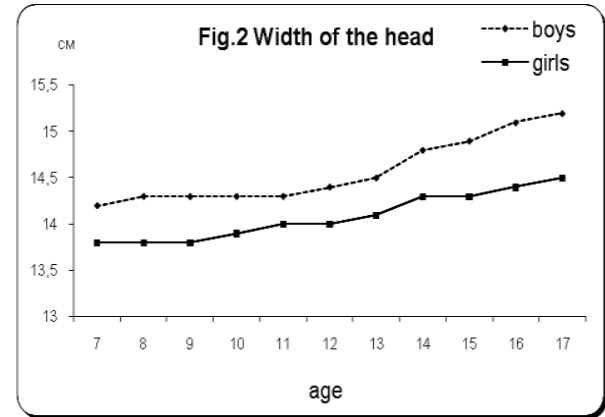

Figure 2. Width of the head

The growth of head length in boys stops after the age of 16, and in girls even earlier 13-14, with the exception of the unexpected reduction in 15-year-old girls, which can be explained with the specificity of the transversal sample. 
The average width of the head (figure 2) in all age groups was significantly greater in boys ( $\mathrm{p} \leq 0.05)$, as the differences in 7 -year-olds are $0.45 \mathrm{~cm}$, and in 17 -year-olds they are $0.51 \mathrm{~cm}$. The maximum annual growth for boys was between $13-14$ years $(0.22 \mathrm{~cm})$, and for girls between $9-10$ and $12-13(0.16 \mathrm{~cm})$. For 11 - year-olds the width has increased by 0.77 $\mathrm{cm}$ in boys, which accounts for $94.87 \%$ of its baseline values. In girls, the head width has increased by $0.71 \mathrm{~cm}$, or $95.10 \%$.

Our results showed that the width feature of the head for boys practically stops to grow after the age of 16, while for girls it continues to grow though with less intensity $-0.06 \mathrm{~cm}$.

The height of the head (figure 3), throughout the observed growth period, is again greater in boys, with statistically significant gender differences $(p \leq 0.05)$. The differences between boys and girls at the age of 7 are $0.62 \mathrm{~cm}$, while at the age of 17 they are $0.76 \mathrm{~cm}$. In boys, an intensive growth can be seen in three age intervals: at the age 7 and $8(0.22 \mathrm{~cm}), 12$ and $13(0.26 \mathrm{~cm})$ and 16 and $17(0.28 \mathrm{~cm})$. In girls, the maximum annual growth was found in two age intervals: at the age of 8 and 9 year $(0.26 \mathrm{~cm})$ and 12 and $13(0.27 \mathrm{~cm})$.

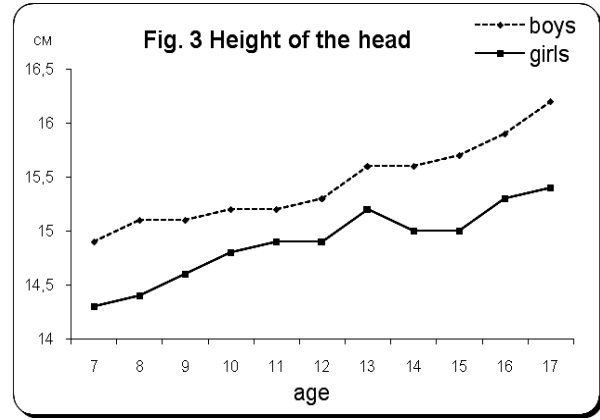

Figure 3. Height of the head

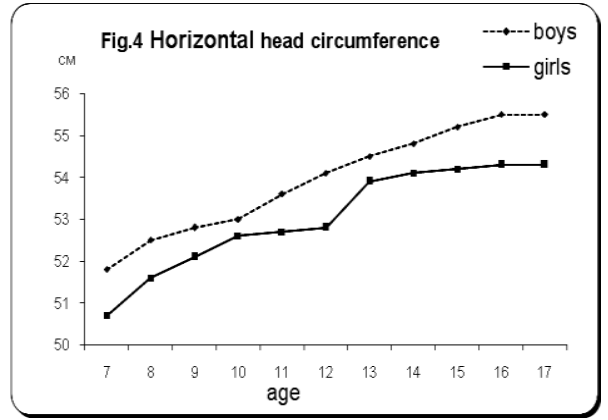

Figure 4. Horizontal head circumference

During the observed age period, the head height has increased by $1.28 \mathrm{~cm}$ for boys, which is $92.09 \%$ of its baseline values for the 7-year-old boys. In girls, it has increased by $1.14 \mathrm{~cm}$ or $92.61 \%$.

In the children from the Eastern Rhodope region, unlike the length and width, the head height in both sexes continues to grow after the age of 16, which is not confirmed for the population from Smolyan (Mladenova, 2003), while for the population from Plovdiv it is valid only for boys (Nikolova, 2008).

As far as the horizontal head circumference is concerned (figure 4), the results showed no statistical significance only in children at the age of $10(\mathrm{p} \leq 0.05)$. The gender differences of 7-year-olds are $1.03 \mathrm{~cm}$, and of 17-year-olds they reach $1.14 \mathrm{~cm}$. For boys and girls two peaks of growth were found. The first peak in both sexes is between the ages of 7 and $8(0.68$ $\mathrm{cm}$ in boys, and $0.84 \mathrm{~cm}$ in girls). The second is between the ages of 10 and 11 for boys $(0.69$ $\mathrm{cm})$, while in girls one year later - between 12 and $13(1.12 \mathrm{~cm})$.

Within the period between 7 to 17 years of age the head circumference has increased by $3.70 \mathrm{~cm}$ for boys and $3.59 \mathrm{~cm}$ for girls, which is respectively $93.33 \%$ and $93.39 \%$ of its baseline sizes in 7-year-olds. In both sexes the horizontal head circumference stops to increase after the age of 16 , which is confirmed by the results for the children from Plovdiv and Smolyan as well. The growth of the facial part of the head differs from the cranial part due to their different formation. If the dimensions of the cranial part of the head for 7-yearolds reaches $95 \%$ of the values of 17 -year-olds, the width dimensions of the facial part reach $86 \%$, and those of the height $-87 \%$.

Our findings have shown similar type of growth curves for the cephalo-facial features, which again are characterized by significantly higher values in boys (Figure $5-8$ ). In 7-year- 
old girls facial widths and heights are $90 \%$ of those of 17 -year-olds, while in 7-year-old boys they are $86 \%$. These results confirm the more intensive growth of facial dimensions in girls, and for them after the age of 16 these features stop growing, while in boys the growth rate remains relatively high after that age, a fact which is confirmed for the populations from Smolyan and Plovdiv (Mladenova, 2003, Nikolova 2008). It is worth mentioning that in the children from the three regions the width facial features stop developing earlier than these of the height, which is typical for both sexes and particularly pronounced in boys.

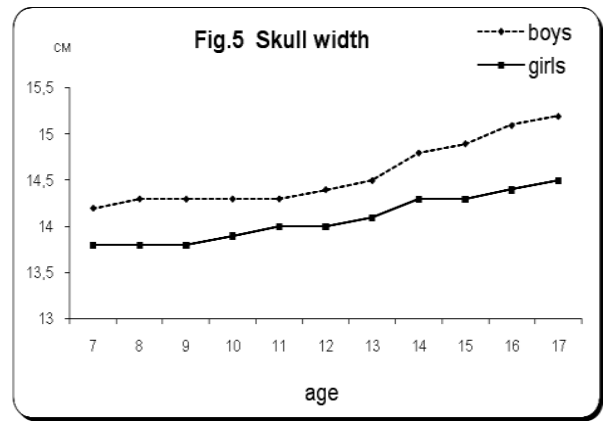

Figure 5. Scull width

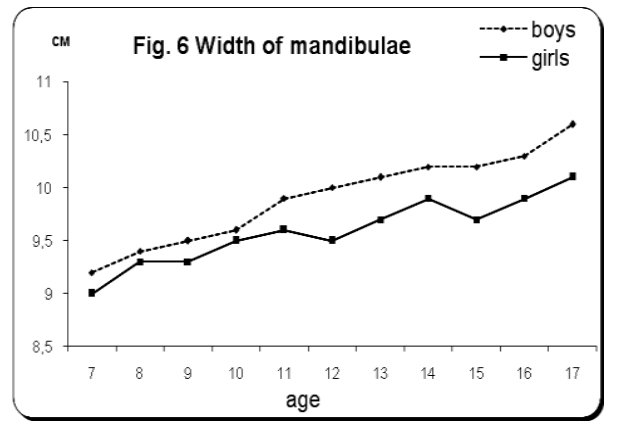

Figure 5. Width of mandibulae

The comparative evaluation of the intensity of growth has shown that the length, head circumference and mandibular width increase most intensively between 10 and 11 years of age in boys, and the height features of the head, and face between 12 and 13 years of age. In girls, the intensity of growth processes for the majority of head and facial features are more concentrated in the age period between 12-13. Besides the absolute values of metric features, the indices of proportionality are widely used in anthropology, and they give some insight into the shape of the head as a whole, as well as the individual parts of it.

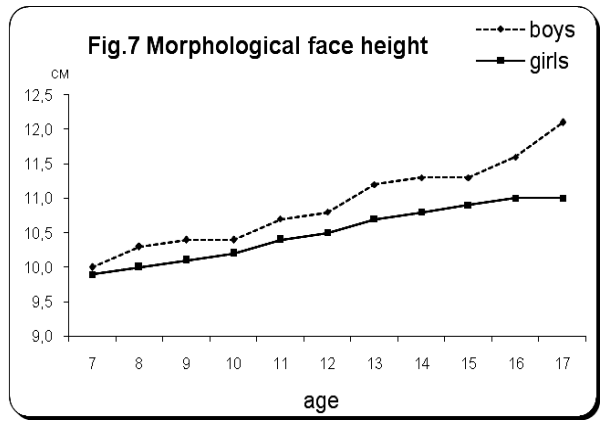

Figure 7. Morphological face height

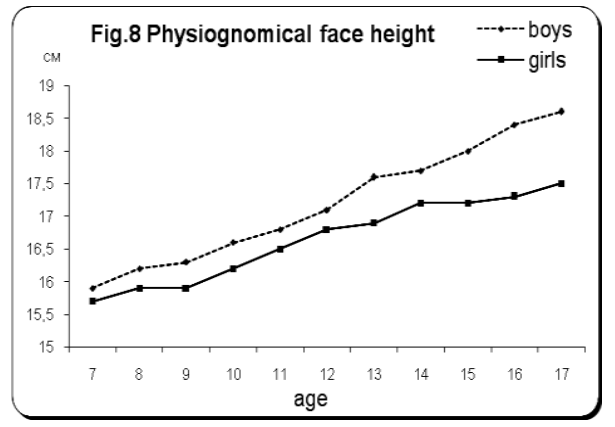

Figure 8. Physiognomical face height

According to literature data, the head index decreases with advancing age. This regularity was not observed in our data. According to Martin-Saller's rubrication for the head index, the form of head of the examined children and adolescents, in all age groups, is from the category "mesocephalic", reflecting the accelerated development of head in height in comparison to width. The results of our study showed lower average values of head index in 17-year-olds from the Eastern Rhodope, in comparison with the grown of men and women from Haskovo (Yordanov, 2006). 
According to the analysis of the morphological facial index, for the face shape, we have found that wider facial shapes dominate in the beginning of the growth period in both sexes, which is especially expressed in boys, and narrower facial shapes - during the puberty and the period of post-puberty, which is well manifested in girls. Individuals at the age of 17 have index valuestypical for the grown men and women from Haskovo region.

The index of width proportionality between the middle and lower facial parts showed that girls have relatively bigger mandibular width, while boys have relatively greater cheekbone width. According to Lundborg-Linders-Saller's rubrication boys of all ages fall in the category "medium", and the girls "broad-face".

The results of our study have shown that 17 -year-old boys and girls from the region of observation differ in the shape of the head from the grown men and women, while their facial shape is the same.

\section{Conclusions}

Boys have higher dimensions of the features that characterize the cranial and facial parts of the head than girls.

The dimensions of the cranial part are ahead in their development in comparison to the dimensions of the facial part of the head, as it was observed in both sexes.

In both boys and girls, the width cephalometric features complete their growth earlier than the height features.

The shape of the head in the children and adolescents under observation is from the category "mesocephalic", and wider facial shapes dominate for both sexes.

\section{Referenses}

Jordanov J, et al. Anthropology of the population of Bulgaria in the late twentieth century. Academic Publishing House "Prof. M. Drinov ", Sofia, 2006, 435.

Martin R, Sailer K. Lehrbuch der Anthropologic. Band 1. Stuttgart: Gustav Fischer Verlag, 1957, p. 661.

Mladenova C. Anthropological characteristics of growth and development of children and adolescents from Smolyan region in the modern conditions of life. Abstract. Plovdiv, 2003, p. 1-58.

Nikolova M. Proceedings of the tabular and graphic data on growth and development of children from Plovdiv. Publishing House "Paisii Hilendarsky", Plovdiv, 2008, p. 201.

Tanner JM. A History of the Study of Human Growth. Cambridge Univ. Press, Cambridge, 1981, p. 356.

\section{CEFALOMETRIJSKE KARAKTERISTIKE DECE I ADOLESCENATA IZ REGIONA ISTOČNIH RODOPA - BUGARSKA}

\section{Sažetak}

Cilj ovog rada je karakterizacija starosne dinamike i specifičnost razvojnih procesa glave kod dece i adolescenata iz regiona Istočnih Rodopa. Da bi se postigao ovaj cilj koristili smo podatke prikupljene od 1481 dece i adolescenata. Osam karakteristika glave i crta lica su mereni klasičnom metodologijom Martin-Saller (1957). Na osnovu direktno evidentiranih karakteristika, izračunati su četiri indeksa. To je osobenost postnatalnog rasta svih cefalometrijskih karakteristika za koje se krive rasta se ne presecaju. Rezultati pokazuju da dečaci imaju veće vrednosti koje karakterišu kranijalne i facijalne delove glave od onih kod devojaka. Dimenzije lobanje su u razvojnoj prednosti u odnosu na dimenzije lica kod oba pola. U oba pola, širina cefalometrijskih karakteristika završi rast ranije nego visina. Oblik glave u dece i adolescenata je iz kategorije mezocefalilčnih i širi facijalni oblici dominiraju u oba pola.

Ključne reči: cefalometrijske karakteristike, deca, mezocefaličnost 